\title{
Current Standard and Future Perspectives in the Treatment of Gastrointestinal Stromal Tumors
}

\author{
Silke Cameron $^{\mathrm{a}}$ Alexander Beham $^{\mathrm{b}}$ Hans-Ulrich Schildhaus ${ }^{\mathrm{c}}$ \\ ${ }^{a}$ Clinic for Gastroenterology and Gastrointestinal Oncology, ${ }^{\text {b } C l i n i c ~ f o r ~ G a s t r o i n t e s t i n a l, ~ V i s c e r a l ~ a n d ~}$ \\ Pediatric Surgery, and ${ }^{C}$ Institute of Pathology, University Medicine, Göttingen, Germany
}

\section{Keywords}

Gastrointestinal stromal tumors - Tyrosine kinase

inhibitors · Diagnosis and treatment

\begin{abstract}
The origin of gastrointestinal stromal tumors (GIST) from interstitial cells of Cajal or their precursor cells has been understood since the early 1990s. The first mutations within the KIT-gene have been described in the late 1990s. Even though these mutations were the breakthrough of small molecular therapy, we still do not know the factors responsible for their malignant transformation. Until then, we can only speak of recurrence risk. This review gives an introduction on the current understanding of GIST and highlights the remaining questions for diagnosis, tumor progression, and treatment in progressive disease.

(c) 2017 S. Karger AG, Basel
\end{abstract}

\section{Introduction}

Within gastrointestinal stromal tumors (GIST) are rare $(0.2 \%)$ [1]. Their incidence is about $1.5 / 100.000$ per year $[2,3]$. GIST originate from the myenteric interstitial pacemaker cells of Cajal or their precursor cells [4-6]. They are hence mesenchymal tumors of the gastrointes- tinal tract. However, in large GIST, the connection to the gastrointestinal tract might be lost $[7,8]$. Their most common location is the stomach (about $60 \%$ ), followed by the small intestine (25-30\%) and the colon (5\%). Within the gut, GIST manifestations seem to vary further: GIST of the esophagus are rare $(1 \%)[9,10]$. GIST of the stomach fundus seem to differ from GIST of the corpus or antrum of the stomach (own observation). Small intestinal GIST mainly manifest in the ileum and colorectal GIST mainly manifest in the rectum $[10,11]$. This might be, at least in part, attributed to the network of pacemaker cells within the gut [12-14].

The mean age at diagnosis of sporadic GIST lies between 55 and 65 years, with a slightly higher prevalence in men $[10,15]$. No external risk factors such as smoking or nutrition have yet been identified.

Whilst gastric GIST rather manifest with bleeding, symptoms of small intestinal GIST include abdominal pain due to intestinal obstruction. In about $20 \%$ of the cases, GIST are incidentally found during endoscopy.

Endoscopically, GIST present as submucosal protrusion. Differential diagnoses distinguish lesions originating in the tela submucosa, such as lipoma (neuro)fibroma, plexiform fibromyxoma, inflammatory fibroid polyp, perineurinoma, glomus tumor, ectopic pancreatic tissue, submucosal cysts, varicous vains, and vascular tumors, from lesions originating in the tunica muscularis,

\section{KARGER}

(c) 2017 S. Karger AG, Basel

E-Mail karger@karger.com

www.karger.com/dig
PD, Dr. Silke Cameron

Clinic of Gastroenterology and Gastrointestinal Oncology

University Medicine Göttingen

Robert-Koch-Str. 40, DE-37075 Göttingen (Germany)

E-Mail silke.cameron@med.uni-goettingen.de 
Fig. 1. a Endoscopic image of small GIST in the cardia of the stomach. b Above, endosonography (longitudinal scanner) showing the origin within the muscle layer. Below, endosonographic puncture of the GIST.
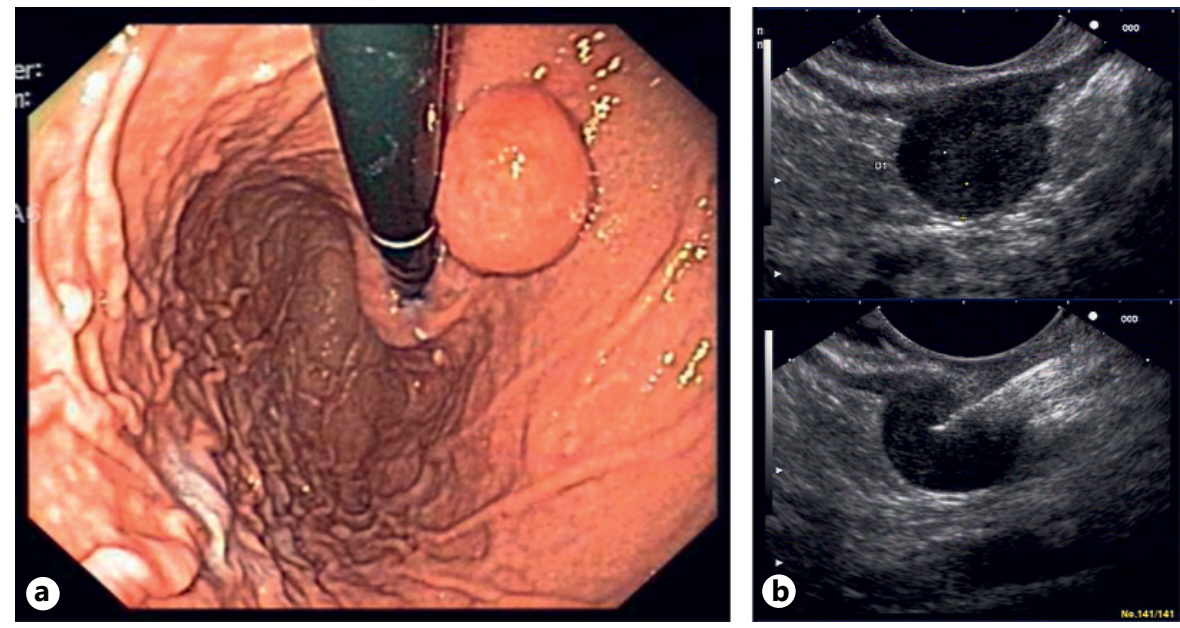

such as leiomyoma, leiomyosarcoma, schwannoma and granular cell tumors - or GIST [16, 17]. Of note, metastases can manifest in all these layers. One should further be aware of impressions from adjacent organs. This explains the role of endoscopic ultrasound in the diagnosis of GIST (Fig. 1). Endosonography can mostly attribute the origin of GIST to the muscle layer. It further makes assessment of the echogeneity possible. GIST are typically hypoechoic. They present as single nodules but can be polycylic with echogene foci and cystic changes [16].

Biopsies have to reach the submucosa and can thus only be performed as incision biopsies by mucosal dissection with an endoscopic knife (cave: GIST are highly vascularized). An alternative is the endosonographic fine-needle aspiration or endosonography-guided whole-core biopsy. These techniques allow the measurement of the tumor size, histopathological diagnosis (including morphology: spindle cell, epitheloid or mixed; and immunohistochemistry: that is, CD117 [c-kit], DOG-1), and mutation analysis of stomach, duodenal, and rectum GIST. Analysis of the number of mitosesin 50 high power fields $\left(5 \mathrm{~mm}^{2}\right)$ isfeasibleonly from the operation specimen. GIST size, location, and mitotic count, however, are necessary for the risk classification of GIST (Table 1a) [11]. The proper TNM classification does not apply, as these tumors do not grow infiltrative, and lymph node metastasis is negligible in primary sporadic GIST. Nevertheless, the TNM-classification has been modified to fit the requirements of the classification of GIST (Table 1b) [18]. There is a general working agreement that GIST should be classified according to both classifications, as the UICC/TNM classification of GIST has not yet been validated in clinical routine. Treatment decisions are based on the AFIP-risk classification by Miettinen and Lasota
[11]. Furthermore, a special effort should be made in describing serosa infiltration and perforation, as perforation of the serosa by tumor cells accounts for micro-metastasis. It would also be advisable to describe necrosis and tumor cellularity. This might be important for understanding and predicting the clinical course of intermediate GIST.

Furthermore, a genotype-phenotype correlation has been described. KIT-mutations mostly have spindle-cell morphology, whereas PDGFRA-mutated GIST (of the stomach) show epitheloid or mixed-cell morphology [7]. Mutations in KIT Exon 11 codon 557/558 are prognostically unfavorable [19]. Deletions are more critical for recurrence-free survival than point mutations [20]. The mutational spectrum of KIT Exon 9 mutations is relatively broad. They occur mostly in the small intestine and lead more often to peritoneal than liver metastasis. However, their association with high risk or metastasis per se is not increased [21].

Even though GIST are mostly sporadic, KIT- or PDGFRA-signaling-driven mesenchymal tumors, pediatric or juvenile GIST [22], and familial GIST have been described [23]. Pediatric GIST (GIST diagnosed at the age of 18 or younger) account for $1-2 \%$ of GIST cases with female predominance $[22,24,25]$. They are mostly located in the stomach with multiple nodules $[22,24,26]$. Pediatric GIST lack KIT and PDGFRA mutations and thus seem to have different genetic drivers when compared to sporadic adult GIST. Juvenile GIST can present with KIT and PDGFRA mutations, and lymph node metastasis has been described [26]. Post-translational modification has been proposed to account for the differences in the KIT receptor in juvenile GIST [27]. In both, pediatric and juvenile GIST, gene expression analysis showed 
Table 1.

a Risk classification according to Miettinen and Lasota [11] (AFIP-criteria), modified according to Agaimy [49]

\begin{tabular}{|c|c|c|c|c|c|}
\hline \multicolumn{2}{|c|}{ Tumor parameter } & \multicolumn{4}{|c|}{ Risk of recurrence/metastasis after primary GIST resection } \\
\hline Mitotic rate & size, $\mathrm{cm}$ & stomach & duodenum & jejunum/ileum & rectum \\
\hline \multirow[t]{4}{*}{$\leq 5$ pro $50 \mathrm{HPF}$} & $\leq 2$ & No risk & No risk & No risk & No risk \\
\hline & $>2-\leq 5$ & Very low & Low & Low & Low \\
\hline & $>5-\leq 10$ & Low & High* & Intermediate & High \\
\hline & $>10$ & Intermediate & High & High & High \\
\hline \multirow[t]{4}{*}{$>5$ pro $50 \mathrm{HPF}$} & $\leq 2$ & No risk & Not enough data & High & High \\
\hline & $>2-\leq 5$ & Intermediate & High & High & High \\
\hline & $>5-\leq 10$ & High & High & High & High \\
\hline & $>10$ & High & High & High & High \\
\hline
\end{tabular}

* Few cases.

b UICC-classification, adapted from Sobin et al. [50], where T1 $<2 \mathrm{~cm}$; T2 $>2-5 \mathrm{~cm}$; T3 $>5-10 \mathrm{~cm}$; T3 $>10 \mathrm{~cm}$; mitotic rate: small $\leq 5$ mitoses, high $>5$ mitoses in $5 \mathrm{~mm}^{2}$

\begin{tabular}{lllllll}
\hline Stomach & & Mitotic rate & Node & Metastasis & \multicolumn{2}{c}{ Small intestine/non-gastric } \\
\hline Stage IA & T1, T2 & Low & N0 & M0 & T1, T2 & Stage I \\
\hline Stage IB & T3 & Low & N0 & M0 & T3 & Stage II \\
\hline Stage II & T1, T2 & High & N0 & M0 & T1 & Stage IIIA \\
& T4 & Low & N0 & M0 & T4 & Stage IIIB \\
\hline Stage IIIA & T3 & High & N0 & & & \\
\hline Stage IIIB & T4 & High & N0 & & & Stage IV \\
\hline Stage IV & Any T & Any & N1 & M0 & Any T & \\
& Any T & Any & Any N & M1 & Any T & \\
\hline
\end{tabular}

high expression of phosphorylase kinase alpha 1 (which is involved in muscle glycogen metabolism), Frizzeld 2 (a receptor involved in the Wnt-pathway), neuroligin 4, insulin-like growth factor 1 receptor (IGF1R), and ankyrin-2 (a protein of the neuromuscular junction) [26].

Germline mutations in the KIT or PDGFRA gene predispose for familial GIST. Due to the increase in c-kit expressing cells, hyperpigmentation of the skin (melanocytes) and urticaria pigmentosa (mast cells) are associated with familial GIST [23].

Syndromal GIST can be hereditary or non-hereditary [28]. The main tumor syndromes include neurofibromatosis type 1 von Recklinghausen with typical café-au-lait spots and neurofibromas, the Carney triad (gastric GIST, pulmonary chondroma and extra-adrenal paraganglioma), and germline mutations in KIT and PDGFRA as well as the Carney-Stratakis syndrome (paraganglioma and GIST) [28].
If GIST lack mutations in the KIT or PDGFRA genes, they are designated as wild type (WT). It needs to be kept in mind, that GIST - previously regarded as WT-GIST might carry somatic activation mutations in KIT exon 8 [29]. Approximately $15 \%$ of GIST in adults and $85 \%$ of GIST in children are WT [30]. They are resistant against conventional treatment, such as the imatinib therapy. In the Carney triad, loss of the succinate-dehydrogenase (SDH) beta (SDHB) has been shown, which may be caused by hypermethylation of the promoter region of the SDHB gene. In the Carney-Stratakis syndrome, germline mutations of the SDH subunits $\mathrm{A}, \mathrm{B}, \mathrm{C}$, and $\mathrm{D}$ have been reported [31]. The succinate dehydrogenase complex is part of the citric acid cycle and catalyzes the oxidation of succinate to fumarate. Loss of SDH increases succinate, thus impairing hydroxylation and degradation of $\mathrm{HiF} 1 \alpha$, which then translocates into the nucleus and acts as oncogenic transcription factor. Furthermore, succinate accu- 
mulation inhibits ten-eleven translocation enzymes, which are important for DNA methylation and thus epigenetic programming [32]. In GIST, SDHB-loss can be shown by immunohistochemistry. SDH-deficiency can be associated with the over-expression of IGF1R [30].

Furthermore, in $7 \%$ of WT GIST, mutations in the serine-threonin kinase BRAF mutations (V600E) can be detected [33]. In this context, it has been proposed that the activation of the mitogen-activated protein kinase pathway might be a possible mechanism of primary resistance to imatinib [34]. GIST thus maintain their role as model tumors.

\section{Treatment}

Complete surgical resection is the gold standard. All other treatment considerations follow the feasibility of a complete GIST resection, which does not include lymph node dissection. Medical treatment response depends on the mutational status of the KIT or PDGFRA gene [35]. Hence, for all treatment considerations, mutation analysis should be performed. Secondary resistance is mainly due to second mutations in the corresponding gene.

\section{Neoadjuvant}

Neoadjuvant therapy (with imatinib) can help to render a locally advanced primary GIST resectable or allow organ or function preserving surgery. This can be the case in large stomach GIST, but mostly it is discussed for duodenal or rectal GIST. Prior mutation analysis is required to predict treatment response. The time of neoadjuvant treatment is debated and depends on the response of the tumor to the treatment. Generally, neoadjuvant treatment is performed for 3-4 months with a staging CT thereafter. In larger tumors, it can be extended to 6 months or longer (up to 12 months have been discussed) [36]. However, one should keep in mind that tumor biology might change over long-term treatment.

\section{Adjuvant}

Adjuvant therapy is administered based on the risk classification [11]. Patients with high-risk GIST receive imatinib (400 mg/day) after curative resection [37-39]. It has been shown that adjuvant therapy for 3 years is superior to 1 year [40]. If applicable, the duration of neoadju- vant therapy can be subtracted from adjuvant therapy (empirical consensus). Of note, neoadjuvant therapy hampers mitotic count as a result of tumor regression, and risk classification might be problematic. In case of KIT Exon 9 mutation (which occurs often in small intestinal GIST), the dose of $400 \mathrm{mg}$ imatinib is increased to $800 \mathrm{mg}$, if feasible. For intermediate GIST, adjuvant therapy should be evaluated. Retrospective analyses currently generate predicting factors that support the benefit of adjuvant treatment in subgroups of patients with specific mutations. The American PERSIST-5-trial (NCT00867113), and the Scandinavian-German SSGXXII study analyze the benefit of 5-year adjuvant treatment in high-risk GIST. WT-GIST and GIST with PDGFRA Exon 18 D842V mutation undergo follow-up care, as these mutations do not respond to conventional tyrosine kinase inhibitors [7].

\section{Palliative}

In the palliative situation or after GIST recurrence, imatinib remains the first choice. It is important to know that the primary mutation is also found in GIST metastasis. Hence, imatinib can be restarted at $400 \mathrm{mg}$ or - in case of progression - be elevated to $800 \mathrm{mg}$. However, secondary mutations govern the response to therapy in advanced disease. Especially if progression occurs under therapy, biopsy helps treatment decision. Surgery should be discussed only if complete resection is possible. Incomplete resection does not prolong survival. After the resection of the metastasis, tyrosine kinase inhibitor treatment should be continued and comply with the mutation, which might have triggered treatment resistance. As regards perioperative treatment interruption, only empirical data are available [7]. In case of a scheduled operation, imatinib treatment is typically interrupted from the day of the operation (or one day prior) until wound healing is complete. Of note, sunitinib and sorafenib have a longer plasma half-life as well as antiangiogenic activity. In general, mutation analysis is awaited for the postoperative treatment decision and will be proposed by the tumor board. While sunitinib $(37,5 \mathrm{mg} /$ day without treatment interruption) is given primarily for KIT Exon 9 mutation, it was also shown to be effective in mutations within the tyrosine kinase domain 1 (the ATP-binding site), which is coded by KIT Exon 13 and 14 (notably codon V654A and T670I, respectively) [41, 42]. Sorafenib $(2 \times 400 \mathrm{mg} /$ day $)$ is given for secondary mutations involving mutations in the tyrosine kinase 1 and 2 domains (activation loop) $[43,44]$. In case of side effects such as diarrhea or hand-and-foot syndrome, the dose is reduced to $2 \times 200$ 
Table 2. Recent studies in advanced or metastatic GIST

\begin{tabular}{|c|c|c|c|c|}
\hline Medication & Study & Phase & Treatment line & Outcome \\
\hline $\begin{array}{l}\text { Regorafenib }(10 \mathrm{mg}) \text { alternating } \\
\text { with imatinib }(400 \mathrm{mg})\end{array}$ & $\begin{array}{l}\text { ALT GIST } \\
\text { NCT02365441 }\end{array}$ & Phase II & First-line & \\
\hline Dasatinib $(2 \times 70 \mathrm{mg})$ & & & Third-line & $\begin{array}{l}\text { mPFS } 2 \text { months; mOS } 19 \\
\text { months; mPFS for WT } \\
\text { GIST } 8.4 \text { months }\end{array}$ \\
\hline $\begin{array}{l}\text { Everolimus }(2.5 \mathrm{mg}) \text { plus } \\
\text { imatinib }(600 \mathrm{mg})\end{array}$ & NCT01275222 & Phase I/II & Second- and third-line & 14.9 vs. 10.7 months mOS \\
\hline Crenolanib & $\begin{array}{l}\text { BLU-285 } \\
\text { NCT02508532 }\end{array}$ & Phase I & PDGFRA exon 18 D842V & \\
\hline Crenolanib & NCT01243346 & Phase II & PDGFRA exon 18 D842V & \\
\hline Pazopanib (800 mg/day) & $\begin{array}{l}\text { PAZOGIST } \\
\text { NCT01323400 }\end{array}$ & Phase II & Third-line & $\begin{array}{l}\text { mPFS } 3.4 \text { vs. } 2.3 \text { months } \\
\text { BSC }\end{array}$ \\
\hline $\begin{array}{l}\text { Dovitinib ( } 500 \mathrm{mg} / \text { day, } 5 \text { days on, } \\
2 \text { days off) }\end{array}$ & NCT01478373 & & Second-line & $\begin{array}{l}\text { Anti-tumor activity in } \\
52.6 \%\end{array}$ \\
\hline Cediranib (45 mg) & NCT00385303 & Phase II & Second-line & $\begin{array}{l}26 / 26 \text { patients did not } \\
\text { complete the study }\end{array}$ \\
\hline $\begin{array}{l}\text { MEK162 (dose finding) plus } \\
\text { imatinib ( } 400 \mathrm{mg} \text { ) }\end{array}$ & NCT01991379 & Phase I + II & First-line & \\
\hline
\end{tabular}

PFS, progression free survival; OS, overall survival; BSC, best supportive care.

mg. However, sorafenib has not officially been approved for the treatment of metastatic GIST, as regorafenib was recommended for this indication $[45,46]$. Recently (in April 2016), regorafenib has been taken from the German market, as the benefit-cost ratio together with relevant side effects was not estimated appropriately. It can however be imported, if justified [47].

In complex cases, a second opinion of an experienced center should be inquired, also not to overlook clinical studies, which are currently being carried out.

\section{Future Perspectives}

Several multikinase inhibitors are being tested for the treatment of advanced or metastatic GIST (Table 2). In preclinical studies, ponatinib was shown to be encouraging, as it has multiple binding sites and locks the KIT receptor in an inactive conformation, a promising acting mechanism [48]. As GIST are rare tumors of the gastro- intestinal tract, mutation-driven studies remain difficult to undertake. The only example for this approach is the imatinib-resistant PDGFRA Exon 18 D842V-mutation: apart from tentative administration of dasatinib or local therapy of the metastasis with, that is, trans-arterial embolization (TAE, TACE) or radio-frequency ablation, clinical studies with crenolanib seem to be the only promising treatment option. Masitinib would be an option for WT-GIST - however, clinical studies advance slowly, even though preliminary results are promising. Also, combination treatment warrants consideration.

\section{Open Questions}

Many open questions remain in the study of GIST.

- Why do GISTs generally not metastasize into lymph nodes?

- While micro-GIST already have the basic tyrosine kinase receptor mutation, why do they remain silent? 
What would be the second event for tumor development?

- Does the origin as neuronal pacemaker cells play a role for tumor growth; for instance - can changes in the membrane potential influence proliferation?

- Do epigenetic changes trigger a more aggressive behavior?

- Are secondary mutations secondary or do they represent clonal selection/expansion during treatment?

- What is the role of the immune system, which seems to be inhibited within the microenvironment of GIST?
- What about secondary cancers - such as prostate cancer, which seem to be common in patients with GIST? Does tyrosine kinase inhibitor treatment play a role?

- Are WT-GIST a different family of GIST?

These are some questions that can be resolved only with the cooperation of experts in different fields.

\section{Disclosure Statement}

The authors certify that no funding has been received for this article and that they have no conflicts of interest.

\section{References}

1 Blackstein ME, Blay JY, Corless C, Driman DK, Riddell R, Soulieres D, Swallow CJ, Verma S: Gastrointestinal stromal tumours: consensus statement on diagnosis and treatment. Can J Gastroenterol 2006;20:157-163.

2 Nilsson B, Bumming P, Meis-Kindblom JM, Oden A, Dortok A, Gustavsson B, Sablinska K, Kindblom LG: Gastrointestinal stromal tumors: the incidence, prevalence, clinical course, and prognostication in the preimatinib mesylate era - a population-based study in western Sweden. Cancer 2005; 103:821829.

3 Reid R, O'Dywer P, MacDuff E, White J, Cowie F, Currie D, Wall L, Niblock P, Walsh S: Guidelines for the management of gastrointestinal stromal tumors (GIST) in Scotland, 2009, pp 1-63.

4 Heinrich MC, Corless CL, Duensing A, McGreevey L, Chen CJ, Joseph N, Singer S, Griffith DJ, Haley A, Town A, Demetri GD, Fletcher CD, Fletcher JA: PDGFRA activating mutations in gastrointestinal stromal tumors. Science 2003;299:708-710.

5 Hirota S, Isozaki K, Moriyama Y, Hashimoto K, Nishida T, Ishiguro S, Kawano K, Hanada M, Kurata A, Takeda M, Muhammad Tunio G, Matsuzawa Y, Kanakura Y, Shinomura Y, Kitamura Y: Gain-of-function mutations of ckit in human gastrointestinal stromal tumors. Science 1998;279:577-580.

6 Huizinga JD, Thuneberg L, Kluppel M, Malysz J, Mikkelsen HB, Bernstein A: W/kit gene required for interstitial cells of Cajal and for intestinal pacemaker activity. Nature 1995; 373:347-349.

7 Agaimy A, Bauer S, Beham A, Bertolini J, Haller F, Koschny R, Maier J, Montemurro M, Perez D, Schaefer IM, Schildhaus HU, Wurst C, Cameron S: [Gastrointestinal Stromal Tumours (GIST) - development in pathology, surgery and medical therapy. Developed during the 10th German GIST-meeting, Göttingen]. Z Gastroenterol 2015;53:235243.
8 Joensuu H, Vehtari A, Riihimaki J, Nishida T, Steigen SE, Brabec P, Plank L, Nilsson B, Cirilli C, Braconi C, Bordoni A, Magnusson MK, Linke Z, Sufliarsky J, Federico M, Jonasson JG, Dei Tos AP, Rutkowski P: Risk of recurrence of gastrointestinal stromal tumour after surgery: an analysis of pooled population-based cohorts. Lancet Oncol 2012;13:265-274.

9 Lott S, Schmieder M, Mayer B, Henne-Bruns D, Knippschild U, Agaimy A, Schwab M, Kramer K: Gastrointestinal stromal tumors of the esophagus: evaluation of a pooled case series regarding clinicopathological features and clinical outcome. Am J Cancer Res 2014; 5:333-343.

10 Miettinen M, Lasota J: Gastrointestinal stromal tumors (GISTs): definition, occurrence, pathology, differential diagnosis and molecular genetics. Pol J Pathol 2003;54:3-24.

11 Miettinen M, Lasota J: Gastrointestinal stromal tumors: pathology and prognosis at different sites. Semin Diagn Pathol 2006;23:7083.

12 Kenny SE, Connell G, Woodward MN, Lloyd DA, Gosden CM, Edgar DH, Vaillant C: Ontogeny of interstitial cells of Cajal in the human intestine. J Pediatr Surg 1999;34:12411247.

13 Vanderwinden JM, Rumessen JJ: Interstitial cells of Cajal in human gut and gastrointestinal disease. Microsc Res Tech 1999;47:344360.

14 Vanderwinden JM: Role of interstitial cells of Cajal and their relationship with the enteric nervous system. Eur J Morphol 1999;37:250256.

15 ESMO/European Sarcoma Network Working Group: Gastrointestinal stromal tumours: ESMO Clinical Practice Guidelines for diagnosis, treatment and follow-up. Ann Oncol 2014;25(suppl 3):iii21-iii26.

16 Cameron S, Ramadori G: Gastrointestinal stromal tumors: diagnostics, therapy and beyond? Minerva Gastroenterol Dietol 2009;55: 409-423.
17 Papanikolaou IS, Triantafyllou K, Kourikou A, Rosch T: Endoscopic ultrasonography for gastric submucosal lesions. World J Gastrointest Endosc 2011;3:86-94.

18 Wittekind C, Asamura H, Sobin LH, (Hrsg): TNM Atlas, Ed 6, Wiley-Blackwell, 2014.

19 Emile JF, Ray-Coquard I, Bui B, Adenis A, Bertucci F, Dufaud F, Cupissol D, Chevreau C, Bompas E, Coindre JM, Mir O, Perol D, Chabaud S, Blay JY, LeCesne A: Relationship of the topography of KIT exon 11 alterations and predictive value for PFS in patients with advanced GIST: results of the BFR14 prospective French Sarcoma Group randomized phase III trial. J Clin Oncol 2013;31(suppl):abstr 10542.

20 Martin-Broto J, Gutierrez A, Garcia-del-Muro X, Lopez-Guerrero JA, Martinez-Trufero J, de Sande LM, Lainez N, Maurel J, De Juan A, Losa F, Andres R, Casado A, Tejido PG, Blanco R, Carles J, Bellmunt J, Gomez-Espana A, Ramos R, Martinez-Serra J, Llombart-Bosch A, Poveda A: Prognostic time dependence of deletions affecting codons 557 and/or 558 of KIT gene for relapse-free survival (RFS) in localized GIST: a Spanish Group for Sarcoma Research (GEIS) Study. Ann Oncol 2010;21: 1552-1557.

21 Kunstlinger H, Huss S, Merkelbach-Bruse S, Binot E, Kleine MA, Loeser H, Mittler J, Hartmann W, Hohenberger P, Reichardt P, Buttner R, Wardelmann E, Schildhaus HU: Gastrointestinal stromal tumors with KIT exon 9 mutations: update on genotype-phenotype correlation and validation of a highresolution melting assay for mutational testing. Am J Surg Pathol 2013;37:1648-1659.

22 Miettinen M, Sobin LH, Lasota J: Gastrointestinal stromal tumors of the stomach: a clinicopathologic, immunohistochemical, and molecular genetic study of 1765 cases with long-term follow-up. Am J Surg Pathol 2005; 29:52-68.

23 Cameron S, Ramadori G: Familiäre Gastrointestinale Stromatumoren; Thieme Verlag Stuttgart, 2004, pp 189-191. 
24 Agaram NP, Laquaglia MP, Ustun B, Guo T, Wong GC, Socci ND, Maki RG, DeMatteo RP, Besmer P, Antonescu CR: Molecular characterization of pediatric gastrointestinal stromal tumors. Clin Cancer Res 2008; 14 : 3204-3215.

25 Pappo AS, Janeway KA: Pediatric gastrointestinal stromal tumors. Hematol Oncol Clin North Am 2009;23:15-34, vii.

26 Prakash S, Sarran L, Socci N, DeMatteo RP, Eisenstat J, Greco AM, Maki RG, Wexler LH, Laquaglia MP, Besmer P, Antonescu CR: Gastrointestinal stromal tumors in children and young adults: a clinicopathologic, molecular, and genomic study of 15 cases and review of the literature. J Pediatr Hematol Oncol 2005; 27:179-187.

27 Takahashi T, Naka T, Fujimoto M, Serada S, Horino J, Terabe F, Hirota S, Miyoshi E, Hirai T, Nakajima K, Nishitani A, Souma Y, Sawa Y, Nishida T: Aberrant expression of glycosylation in juvenile gastrointestinal stromal tumors. Proteomics Clin Appl 2008;2:12461254.

28 Agaimy A, Hartmann A: [Hereditary and non-hereditary syndromic gastointestinal stromal tumours]. Pathologe 2010;31:430437.

29 Huss S, Kunstlinger H, Wardelmann E, Kleine MA, Binot E, Merkelbach-Bruse S, Rudiger T, Mittler J, Hartmann W, Buttner R, Schildhaus HU: A subset of gastrointestinal stromal tumors previously regarded as wildtype tumors carries somatic activating mutations in KIT exon 8 (p.D419del). Mod Pathol 2013;26:1004-1012.

30 Belinsky MG, Rink L, Flieder DB, Jahromi MS, Schiffman JD, Godwin AK, Mehren MV: Overexpression of insulin-like growth factor 1 receptor and frequent mutational inactivation of SDHA in wild-type SDHBnegative gastrointestinal stromal tumors. Genes Chromosomes Cancer 2013;52:214224.

31 Wada R, Arai H, Kure S, Peng WX, Naito Z: "Wild type" GIST: clinicopathological features and clinical practice. Pathol Int 2016;66: 431-437.

32 Ricci R: Syndromic gastrointestinal stromal tumors. Hered Cancer Clin Pract 2016; 14:15.

33 Agaimy A, Terracciano LM, Dirnhofer S, Tornillo L, Foerster A, Hartmann A, Bihl MP: V600E BRAF mutations are alternative early molecular events in a subset of KIT/ PDGFRA wild-type gastrointestinal stromal tumours. J Clin Pathol 2009;62:613616.

34 Miranda C, Nucifora M, Molinari F, Conca E, Anania MC, Bordoni A, Saletti P, Mazzucchelli L, Pilotti S, Pierotti MA, Tamborini E, Greco A, Frattini M: KRAS and BRAF mutations predict primary resistance to imatinib in gastrointestinal stromal tumors. Clin Cancer Res 2012;18:1769-1776.

35 Corless CL, Barnett CM, Heinrich MC: Gastrointestinal stromal tumours: origin and molecular oncology. Nat Rev Cancer 2011;11: 865-878.

36 Reichardt P, Blay JY, Mehren MV: Towards global consensus in the treatment of gastrointestinal stromal tumor. Expert Rev Anticancer Ther 2010;10:221-232.

37 Casali PG, LeCesne A, Velasco AP, Kotasek D, Rutkowski P, Hohenberger P, Fumigalli E, Judson IR, Italiano A, Broto JM, Gronchi A, Dei Tos AP, Marreaud S, Van der Graaf W, Zalcberg JR, Litiere S, Blay JY: Imatinib failure-free survival (IFS) in patients with localized gastrointestinal stromal tumors (GIST) treated with adjuvant imatinib (IM): the EORTC/AGITG/FSG/GEIS/ISG randomized controlled phase III trial. J Clin Oncol 2013; 31(suppl):abstr 10500

38 DeMatteo RP, Ballman KV, Antonescu CR, Maki RG, Pisters PW, Demetri GD, Blackstein ME, Blanke CD, von Mehren M, Brennan MF, Patel S, McCarter MD, Polikoff JA, Tan BR, Owzar K: Adjuvant imatinib mesylate after resection of localised, primary gastrointestinal stromal tumour: a randomised, double-blind, placebo-controlled trial. Lancet 2009;373:1097-1104.

39 DeMatteo RP, Ballman KV, Antonescu CR, Corless C, Kolesnikova V, von Mehren M, McCarter MD, Norton J, Maki RG, Pisters PW, Demetri GD, Brennan MF, Owzar K: Long-term results of adjuvant imatinib mesylate in localized, high-risk, primary gastrointestinal stromal tumor: ACOSOG Z9000 (Alliance) intergroup phase 2 trial. Ann Surg 2013;258:422-429.

40 Joensuu H, Eriksson M, Sundby Hall K, Hartmann JT, Pink D, Schutte J, Ramadori G, Hohenberger P, Duyster J, Al-Batran SE, Schlemmer M, Bauer S, Wardelmann E, Sarlomo-Rikala M, Nilsson B, Sihto H, Monge OR, Bono P, Kallio R, Vehtari A, Leinonen M, Alvegard T, Reichardt $P$ : One vs three years of adjuvant imatinib for operable gastrointestinal stromal tumor: a randomized trial. JAMA 2012;307:1265-1272.

41 Demetri GD, van Oosterom AT, Garrett CR, Blackstein ME, Shah MH, Verweij J, McArthur G, Judson IR, Heinrich MC, Morgan JA, Desai J, Fletcher CD, George S, Bello CL, Huang X, Baum CM, Casali PG: Efficacy and safety of sunitinib in patients with advanced gastrointestinal stromal tumour after failure of imatinib: a randomised controlled trial. Lancet 2006;368:1329-1338.

42 Heinrich MC, Maki RG, Corless CL, Antonescu CR, Harlow A, Griffith D, Town A, McKinley A, Ou WB, Fletcher JA, Fletcher CD, Huang X, Cohen DP, Baum CM, Demetri GD: Primary and secondary kinase genotypes correlate with the biological and clinical activity of sunitinib in imatinib-resistant gastrointestinal stromal tumor. J Clin Oncol 2008;26: 5352-5359.

43 Heinrich MC, Marino-Enriquez A, Presnell A, Donsky RS, Griffith DJ, McKinley A, Patterson J, Taguchi T, Liang CW, Fletcher JA: Sorafenib inhibits many kinase mutations associated with drug-resistant gastrointestinal stromal tumors. Mol Cancer Ther 2012;11: $1770-1780$.

44 Kindler HL, Campbell NP, Wroblewski K, Maki RG, D'Adamo DR, Chow WA, Gandara DR, Antonescu C, Stadler WM, Vokes EE: Sorafenib (SOR) in patients (pts) with imatinib (IM) and sunitinib (SU)-resistant (RES) gastrointestinal stromal tumors (GIST): final results of a University of Chicago Phase II Consortium trial. J Clin Oncol 2011;29(suppl): abstr 10009.

45 Demetri GD, Reichardt P, Kang YK, Blay JY, Rutkowski P, Gelderblom H, Hohenberger P, Leahy $\mathrm{M}$, von MM, Joensuu $\mathrm{H}$, Badalamenti G, Blackstein M, Le CA, Schoffski P, Maki RG, Bauer S, Nguyen BB, Xu J, Nishida T, Chung J, Kappeler C, Kuss I, Laurent D, Casali PG: Efficacy and safety of regorafenib for advanced gastrointestinal stromal tumours after failure of imatinib and sunitinib (GRID): an international, multicentre, randomised, placebo-controlled, phase 3 trial. Lancet 2013; 381:295-302.

46 Wilhelm SM, Dumas J, Adnane L, Lynch M, Carter CA, Schutz G, Thierauch KH, Zopf D: Regorafenib (BAY 73-4506): a new oral multikinase inhibitor of angiogenic, stromal and oncogenic receptor tyrosine kinases with potent preclinical antitumor activity. Int J Cancer 2011;129:245-255.

47 DGHO: Press Release - [Politischer Streit auf dem Rücken der Krebspatienten - Marktrücknahme von Regorafenib], 2016.

48 Garner AP, Gozgit JM, Anjum R, Vodala S, Schrock A, Zhou T, Serrano C, Eilers G, Zhu M, Ketzer J, Wardwell S, Ning Y, Song Y, Kohlmann A, Wang F, Clackson T, Heinrich MC, Fletcher JA, Bauer S, Rivera VM: Ponatinib inhibits polyclonal drug-resistant KIT oncoproteins and shows therapeutic potential in heavily pretreated gastrointestinal stromal tumor (GIST) patients. Clin Cancer Res 2014; 20:5745-5755.

49 Agaimy A: Gastrointestinal stromal tumors (GIST) from risk stratification systems to the new TNM proposal: more questions than answers? A review emphasizing the need for a standardized GIST reporting. Int J Clin Exp Pathol 2010;3:461-471.

50 Sobin L, Gospodarowicz M, Wittekind C: TNM Classification of Malignant Tumours; The Atrium, Southern Gate, Chichester, West Sussex, PO198SQ, UK, Wiley-Blackwell, 2009. 